九州大学学術情報リポジトリ

Kyushu University Institutional Repository

Comparative analysis of dry matter production and photosynthesis between mungbean (Vigna radiata (L.) and black gram (V. mungo (L.) Hepper) grown in different light intensities

Kubota, Fumitake

Laboratory of Practical Botany, Faculty of Agriculture, Kyushu University

Hamid, Abdul

Agronomy Department, Institute of Postgraduate Studies in Agriculture

https://doi.org/10.5109/23998

出版情報 : 九州大学大学院農学研究院紀要. 37 (1)，pp.71-80，1992-12. Kyushu University バージョン：

権利関係 : 


\title{
Comparative analysis of dry matter production and photosynthesis between mungbean (Vigna radiata (L.) Wilczek) and black gram (V. mungo (L.) Hepper) grown in different light intensities
}

\author{
Fumitake Kubota and Abdul Hamid* \\ Laboratory of Practical Botany, Faculty of Agriculture, \\ Kyushu University 46-01, Fukuoka 812, Japan
}

(Received May 19, 1992)

\begin{abstract}
Both pulse crops, mungbean (Vigna radiata (L.) Wilczek) and black gram ( V. mungo (L.) Hepper), are widely grown and consumed as main protein foods in Bangladesh. In this research light-responses of growth, dry matter production, photosynthesis and leaf or mesophyll conductance were compared between mungbean cultivar Chinese and black gram cultivar MAK-1 grown in different light intensities. Dry matter production and leaf area of black gram decreased with shade, while those of mungbean became the highest under the moderate shade condition (55\% in relative light intensity). The light-photosynthetic response of shade-grown mungbean presented a typical shade-leaf pattern characterized by photosynthetic reduction and low light-saturation point. While in black gram photosynthetic difference was not apparent between control and shade-grown plants, both of which had no light saturation within a light intensity range up to $1,800 \mu \mathrm{mol} \mathrm{m}^{-2} \mathrm{~s}^{-1}$. Mesophyll conductance in shade-grown black gram was considerably higher than that of control plant at a light intensity below $1,000 \mu \mathrm{mol} \mathrm{m}^{-2} \mathrm{~s}^{-1}$, which may suggest the enzymatic activity in $\mathrm{CO}$, fixation system was enhanced under the shade conditions.
\end{abstract}

\section{INTRODUCTION}

Both grain legumes, mungbean (Vigna radiata (L.) Wilczek) and black gram (V. mungo (L.) Hepper), are well known as main crops of protein supplier in Bangladesh (Rhaman and Miah, 1988). Mungbean is superior to black gram in protein quality. While black gram has a higher stability in growth and yield to climatic changes. Agronomic merits and demerits are different between both species (Lawn and Russell. 1978).

In Bangladesh both crops can be grown thrice a year with a cropping period of 2 to 3 months each time. The first sowing time is March to April, the dry season with air temperature increasing; the second is May to June, the beginning of rainy season; and the third is August to October, the end of rainy season.

During the second and third cropping seasons, the climatic conditions are unstable. Large variations in solar radiation and soil moisture content may have great influences on growth of the crops, which has been identified as a major agronomic problem

\footnotetext{
* Agronomy Department, Institute of Postgraduate Studies in Agriculture, Salna, Gazipur 1703, Bangladesh
} 
(Rhaman and Miah, 1988). As the first step to solve the problem, fundamental studies should be made on the response of growth and production to some of the main climatic factors.

General discussion was made on the characteristics of growth and production of tropical leguminous crops including mungbean and black gram (Lawn and Russell, 1978; Lawn, 1989). Photosynthetic ability was evaluated on 20 cultivars of mungbean and a significantly positive relationship was given between yield and photosynthetic rate (Srinivasan et al., 1985). However information is not sufficient in the field of photosynthesis and productive physiology to draw any concrete conclusion.

As a step to clarify the specific characteristics of production system, the response of photosynthesis and dry matter production to light environments has been compared between mungbean and black gram in this research.

\section{MATERIALS AND METHODS}

Mungbean cultivar Chinese and black gram cultivar MAK-1 were used as experimental materials. Both species were sown on Sept.23 1990 in 4.0 liter pots filled with sandy loam soil from Tangail district. The components of chemical fertilizer applied to one pot were $1.6 \mathrm{~g}, 1.2 \mathrm{~g}$ and $2.4 \mathrm{~g}$ in nitrogen, phosphate and potassium, respectively. The plants (two plants/pot) were grown outdoors up to the stage of the fourth or fifth leaf expansion.

Shade treatments were made for 26 days from Oct. 18 to Nov. 13 in the net houses $(2.5 \mathrm{~m} \times 4 \mathrm{~m}$ in area) set in the experimental field of IPSA (Institute of Post Graduate Studies in Agriculture), Bangladesh. The net houses were covered with shade cloths having different light permeabilities to get the three different light intensity levels, $100 \%$ (control, no shade), 55\%(moderate shade) and 30\% (heavy shade). Throughout the experiment soil moisture in pots was adequately maintained by periodical waterings in day time. After start of the shade treatments, the investigations were periodically made on growth characters, dry matter weight, photosynthetic rate and others.

Plant height, leaf area, leaf size and specific leaf area (SLA) were measured as growth characters. Chlorophyll contents in leaf were determined with Chlorophyll Meter (SPAD 502, Minolta) on 30 to 40 spots in young fully-expanded leaves.

Dry matter weight was determined three times, Oct. 18, 29 and Nov.12. Three pots (six plants) were sampled on one occasion for one species in each treatment plot. Sampled plants were divided into five parts, leaf, stem, petiole, reproductive organ and root. Each of them was dried at $80 \mathrm{C}$ for three days and weighed.

On the basis of dry matter weight and leaf area obtained, three production parameters, plant growth rate (PGR), relative growth rate (RGR) and net assimilation rate (NAR), were calculated from the equations (1) to (3) shown below. 


$$
\begin{aligned}
& \mathrm{PGR}=\frac{\mathrm{dw}}{\mathrm{dt}}=\frac{\mathrm{W}_{2}-\mathrm{W}_{1}}{\mathrm{t}_{2}-\mathrm{t}_{1}} \quad \ldots \ldots \ldots \ldots \ldots \ldots \ldots \ldots \ldots \ldots \ldots \ldots \ldots \ldots \ldots \ldots \ldots \ldots \\
& \mathrm{RGR}=\frac{1}{\mathrm{~W}} \cdot \frac{\mathrm{dw}}{\mathrm{dt}}=\frac{\ln \mathrm{W}_{2}-\ln \mathrm{W}_{1}}{\mathrm{t}_{2}-\mathrm{t}_{1}} \\
& \mathrm{NAR}=\frac{1}{\mathrm{~F}} \cdot \frac{\mathrm{dw}}{\mathrm{dt}}=\frac{\ln \mathrm{F}_{2}-\ln \mathrm{F}_{1}}{\mathrm{~F}_{2}-\mathrm{F}_{1}} \cdot \frac{\mathrm{W}_{2}-\mathrm{W}_{1}}{\mathrm{t}_{2}-\mathrm{t}_{1}}
\end{aligned}
$$

where $\mathrm{W}$ is dry matter weight per plant, $\mathrm{t}$ is sampling day and $\mathrm{F}$ is leaf area per plant.

Photosynthetic rates were measured on young fully-expanded leaves with 3 to 5 replications. The measurements were made by an assimilation chamber (closed gas exchange system) connected to Portable Photosynthetic System (Model LI-6200, Licor). The chamber had one liter in capacity. Photosynthetic active radiation (PAR), leaf temperature and relative humidity were recorded simultaneously, and also net photosynthetic rate $(\mathrm{Pn})$, leaf conductance and intercellular $\mathrm{CO}$, concentration $(\mathrm{Ci})$ were automatically calculated and printed out by this model. A leaf with an area of 14 to $18 \mathrm{~cm}^{2}$ was enclosed in the assimilation chamber on measurements of photosynthetic rate. The velocity of air flow through the chamber was adjusted 500 to $600 \mu \mathrm{mols}^{-1}$. The model was programed to read $\mathrm{CO}$, concentrations in the chamber at 10 to 15 second intervals.

Photosynthetic rates, leaf conductances and leaf respiration rates of mungbean and black gram grown in control were measured from 6 to 17 o'clock at one hour intervals on Nov. 1 (a clear day) to determine their diurnal changes. The rates of light -saturated photosynthesis of both species grown in control and shades were measured three times on Oct.18, 29 and Nov.13. Also the light photosynthetic response curves were determined on both species. These measurements were made outdoors before noon. Light intensity on leaf in the assimilation chamber was varied by shade cloths covering. Mesophyll conductance was calculated as a ratio of $\mathrm{Pn} / \mathrm{Ci}$.

Some of mungbean plants grown in shades were infected by yellow mosaic virus and excluded from the experiment.

\section{RESULTS}

\section{Growth characters}

Effects of the shade treatments on plant height, leaf size, SLA and chlorophyll degree are shown in Table 1.

Of these characters, leaf size (length $\mathbf{X}$ width) had a relatively large inter-specific difference. Leaves of mungbean grown in moderate and heavy shades increased to 143 . 3 and $170.9 \%$ in size, respectively. While those of black gram were less variable with light intensity. SLA increased with reduction in light intensity in both species. Mungbean stems were a little elongated under shade conditions, but there was no or 
Table 1. Effect of shade treatments on plant height, SLA, leaf size and chlorophyll degree.

\begin{tabular}{lcccccc}
\hline & \multicolumn{3}{c}{ Mungbean } & \multicolumn{3}{c}{ Black gram } \\
\hline & Control & Moderate & Heavy & Control & Moderate & Heavy \\
Height $(\mathrm{cm})$ & 43.8 & 45.0 & 46.0 & 33.7 & 32.3 & 32.3 \\
SLA $\left(\mathrm{cm}^{2} / \mathrm{g}\right)$ & 247.7 & 325.0 & 362.6 & 196.4 & 225.3 & 297.4 \\
Leaf length $(\mathrm{L}, \mathrm{cm})$ & 10.0 & 12.0 & 13.2 & 6.7 & 7.3 & 7.2 \\
Leaf width $(\mathrm{W}, \mathrm{cm})$ & 12.3 & 14.4 & 16.2 & 12.0 & 12.4 & 11.9 \\
L $\times$ W $\left(\mathrm{cm}^{2}\right)$ & 124.7 & 178.7 & 213.1 & 80.1 & 90.9 & 85.7 \\
Chloro. degree & 48.3 & 44.3 & 42.9 & 50.3 & 48.9 & 46.8 \\
\hline
\end{tabular}

The relative light intensities in the shade treatments (control, moderate and heavy) were 100\% (no shade), $55 \%$ and $30 \%$, respectively.

These parameters were determined on Oct.29, 11 days after the treatment onset. Chlorophyll degree is an index determined by the chlorophyll meter (SPAD).

Table 2. Effect of shade treatments on dry matter weight, top/root ratio and leaf area of a plant in mungbean (A) and Black gram (B).

(A) Mungbean

\begin{tabular}{lcccccccc}
\hline & \multicolumn{9}{c}{ Dry matter weight $(\mathrm{g})$} \\
\cline { 2 - 7 } & Leaf & Stem & Petiole & Repro * & Root & Total & T/R & LA(cm $\left.{ }^{2}\right)$ \\
\hline Control & 6.89 & 3.45 & 1.42 & 0.27 & 1.92 & 13.95 & 6.3 & 965 \\
Moderate & 8.66 & 3.46 & 1.82 & 0.15 & 1.37 & 15.46 & 10.3 & 1517 \\
Heavy & 5.23 & 3.37 & 1.11 & 0.40 & 1.34 & 11.45 & 7.5 & 1430 \\
\hline
\end{tabular}

(B) Black gram

\begin{tabular}{lcccccccc}
\hline & \multicolumn{9}{c}{ Dry matter weight $(\mathrm{g})$} & & \\
\cline { 2 - 6 } & Leaf & Stem & Petiole & Repro* & Root & Total & T/R & LA $\left(\mathrm{cm}^{2}\right)$ \\
\hline Control & 6.48 & 2.72 & 1.27 & 3.22 & 2.25 & 15.94 & 6.1 & 1478 \\
Moderate & 5.26 & 2.65 & 1.12 & 3.41 & 1.45 & 13.89 & 8.6 & 1163 \\
Heavy & 2.49 & 1.41 & 0.49 & 0.88 & 0.88 & 7.90 & 8.0 & 983 \\
\hline
\end{tabular}

These values were determined on Nov. 12, the final sampling day (25 days after the treatment onset). Repro., Reproductive organ.

Table 3. Effect of shade treatments on plant growth rate, relative growth rate and net assimilation rate of mungbean and black gram.

\begin{tabular}{lcccccc}
\hline & \multicolumn{3}{c}{ Mungbean } & \multicolumn{3}{c}{ Black gram } \\
\hline & PGR & PGR & NAR & PGR & PGR & NAR \\
Control & 0.503 & 0.110 & 0.083 & 0.563 & 0.095 & 0.068 \\
Moderate & 0.569 & 0.113 & 0.068 & 0.474 & 0.085 & 0.048 \\
Heavy & 0.405 & 0.098 & 0.051 & 0.254 & 0.067 & 0.026 \\
\hline
\end{tabular}

PGR, g/plant day; RGR, g/g; NAR, g/100 $\mathrm{cm}^{2}$ day. 
little change in black gram. Chlorophyll degrees decreased with shade in both species.

The physical strength of mungbean was greatly reduced by shading, and serious lodgings and petioles drops were observed.

\section{Dry matter production and leaf area}

Effects of the shade treatments on dry matter weight and leaf area are shown in Table 2 .

Total dry matter weight of mungbean grown in heavy shade was $82 \%$ of that $(13$. $95 \mathrm{~g} / \mathrm{plant})$ in control. The highest $(15.46 \mathrm{~g} / \mathrm{plant})$ was obtained in moderate shadegrown plants. While the dry matter weight of black gram decreased from $15.94 \mathrm{~g} /$ plant to $7.90 \mathrm{~g} /$ plant with reduction in light intensity.

Change in leaf area of mungbean showed a different pattern from that of black gram (Table 2). The leaf area of mungbean increased from $965 \mathrm{~cm}^{2} /$ plant (control plant) to $1,517 \mathrm{~cm}^{2} /$ plant or $1,430 \mathrm{~cm}^{2} /$ plant (shade-grown plants), contrary, that of black gram decreased linearly from $1,478 \mathrm{~cm}^{2} /$ plant to $983 \mathrm{~cm}^{2} /$ plant with shade.

Average PGR, RGR and NAR during the treatment period are shown in Table 3. These parameters decreased with reduction in light intensity in black gram, while in

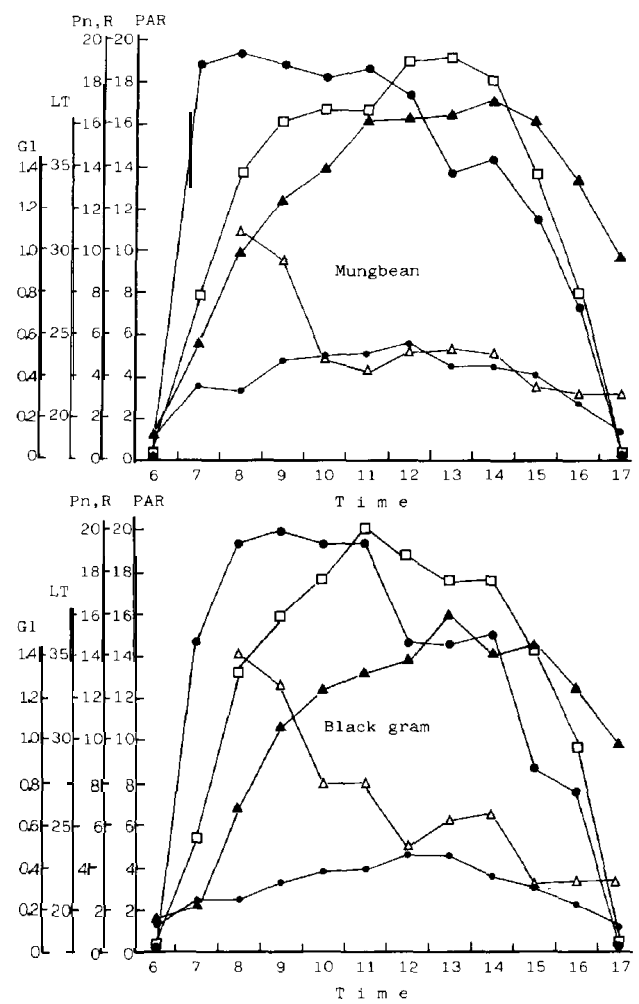

Fig. 1. Diurnal changes in photosynthetic active radiation (PAR, $10^{2} \mu \mathrm{mol} \mathrm{m}^{-2} \mathrm{~s}^{-1}$ ), net photosynthetic rate $\left(\mathrm{Pn}, \mu \mathrm{mol} \mathrm{m}^{-2} \mathrm{~s}^{-1}\right)$, leaf respiration rate $\left(\mathrm{R}, \mu \mathrm{mol} \mathrm{m}^{-2} \mathrm{~s}^{-1}\right)$, leaf temperature (LT, C) and leaf conductance $\left(\mathrm{Gl}, \mathrm{mol} \mathrm{m}^{-2} \mathrm{~s}^{-1}\right)$ in mungbean and black gram.

] ,PAR; $\bullet$,Pn; •, R ; $\Delta, \mathrm{LT} ; \triangle, \mathrm{GL}$. 
mungbean PGR and RGR were highest in moderate shade.

\section{Diurnal changes in photosynthetic rate and leaf conductance}

Diurnal changes in Pn, leaf conductance, leaf respiration rate and leaf temperature of control plants are shown in Fig. 1.

In mungbean Pn reached a maximum level at a PAR of $800 \mu \mathrm{mol} \mathrm{m}^{-2} \mathrm{~s}^{-1}$ at seven o'clock and maintained the level until 11 o'clock. PAR peaked at 12 to 14 o'clock, ranging from 1,900 to $2,000 \mu \mathrm{mol} \mathrm{m}^{-2} \mathrm{~s}^{-1}$, during which Pn had a decreasing trend. Leaf

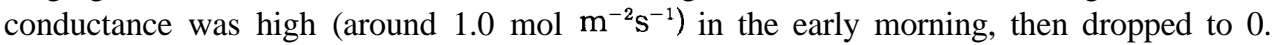
$42 \mathrm{~mol} \mathrm{~m}^{-2} \mathrm{~s}^{-1}$ after 10 o'clock. Photosynthetic rate was not restricted when leaf

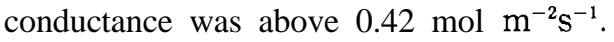

Leaf conductance of black gram was higher than that of mungbean but little difference was apparent in photosynthetic rate and diurnal change between the two species (Fig.1). Leaf temperatures were over $37^{\circ} \mathrm{C}$ in mungbean and over $35^{\circ} \mathrm{C}$ in black gram in the afternoon (Fig.1). The rates of leaf respiration increased with increase in leaf temperature.

\section{Photosynthetic changes with growth}

Gross photosynthetic rates $(\mathrm{Pg}, \mathrm{Pn}+$ dark respiration) in both species grown in control and heavy shade are compared in Fig. 2.

There was almost no change in Pg of control mungbean with growth time, maintaining high levels around $30 \mu \mathrm{mol} \mathrm{m}^{-2} \mathrm{~s}^{-1}$ throughout the three measurement

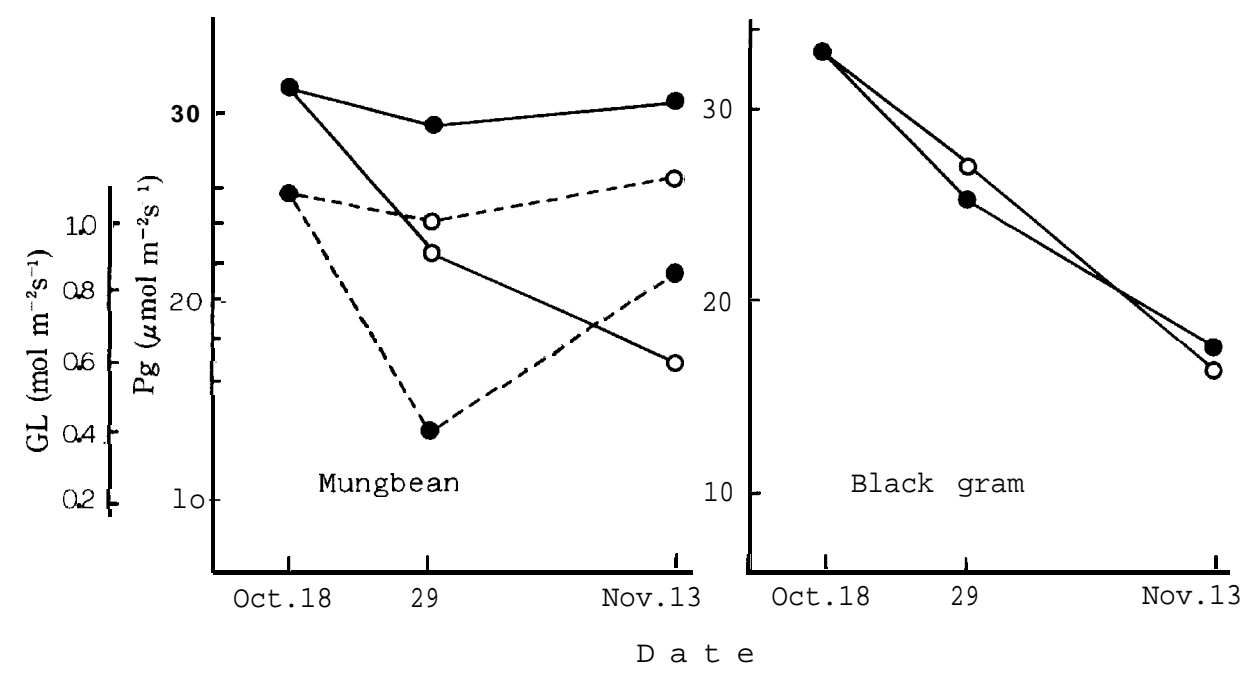

Fig. 2. Effects of shade treatment on the gross photosynthetic rates $(\mathrm{Pg})$ and leaf conductances (GL) of mungbean and black gram grown in control and heavy shade. The measurements were made at PAR over $1,700 \mu \mathrm{mol} \mathrm{m}{ }^{-2} \mathrm{~s}^{-1}$ and at LT from $332^{\circ} \mathrm{C}$ to $36.9-\mathrm{C}$.

$\longrightarrow, \mathrm{Pg} ;-\cdots-, \mathrm{Gl} ; \bullet$, Control ; 0, Heavy shade. 

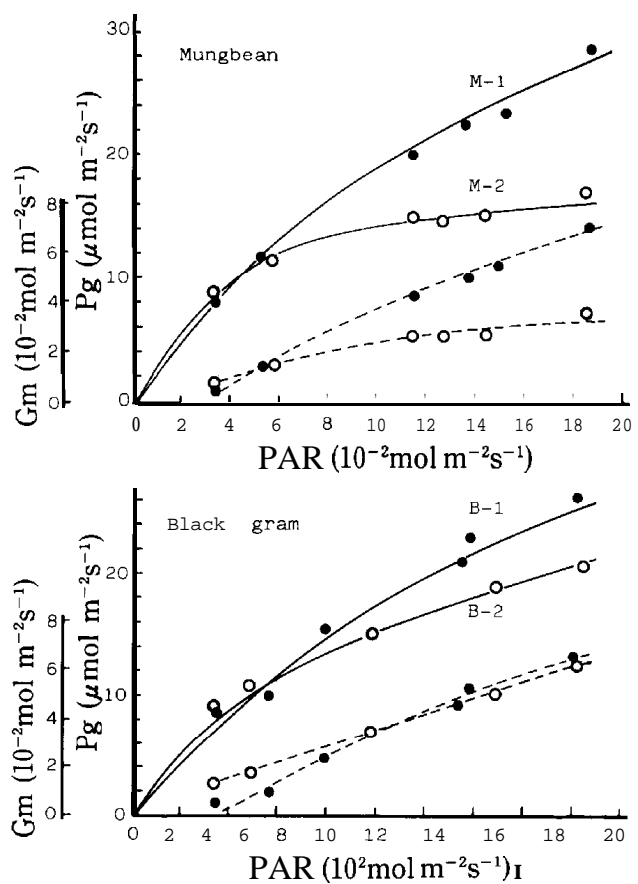

Fig. 3. Light-response curves of the net photosynthetic rates $(\mathrm{Pg})$ and mesophyll conductances $(\mathrm{Gm})$ of mungbean and black gram grown in control and heavy shade. ,$- \mathrm{Pn} ;----, \mathrm{Gm} ; \bullet$, Control ; o, Heavy shade.

Ranges of Gl and LT during the measurements were $1.42 \pm 0.49 \mathrm{~mol} \mathrm{~m}^{-2} \mathrm{~s}^{-1}$ and $35.9 \pm 0.6^{\circ} \mathrm{C}$ in $\mathrm{M}-1,0.60 \pm 0.06 \mathrm{~mol} \mathrm{~m}^{-2} \mathrm{~s}^{-1}$ and $36.8 \pm 0.8^{\circ} \mathrm{C}$ in $\mathrm{M}-2,0.97 \pm 0.06 \mathrm{~mol}$ $\mathrm{m}^{-2} \mathrm{~s}^{-1}$ and $37.2 \pm 0.5^{\circ} \mathrm{C}$ in $\mathrm{B}-1$, and $1.04 \pm 0.16 \mathrm{~mol} \mathrm{~m}^{-2} \mathrm{~s}^{-1}$ and $36.7 \pm 0.6^{\circ} \mathrm{C}$ in $\mathrm{B}-$

2, respectively.

occasions, though leaf conductances were lower and variable. On the other hand, Pg in shade-grown plant decreased from $31.1 \mu \mathrm{mol} \mathrm{m}^{-2} \mathrm{~s}^{-1}$ (Oct.18) to $16.4 \mu \mathrm{mol} \mathrm{m}^{-2} \mathrm{~s}^{-1}$ (Nov. 13), while leaf conductances were constantly high, showing around $1.00 \mathrm{~mol} \mathrm{~m}^{-2} \mathrm{~s}^{-1}$.

For black gram there was little difference in Pg between the treatments (Fig.2); Pg decreased linearly in both control and shade-grown plants from $32.8 \mu \mathrm{mol} \mathrm{m}^{-2} \mathrm{~s}^{-1}$ to around $16.7 \mu \mathrm{mol} \mathrm{m}^{-2} \mathrm{~s}^{-1}$ with maturity.

\section{Light-photosynthetic response curves}

Light responses of $\mathrm{Pg}$ and mesophyll conductance in both species grown in control and heavy shade are shown in Fig. 3.

$\mathrm{Pg}$ of mungbean grown in shade was lower than that of control plant at light intensities above $500 \mu \mathrm{mol} \mathrm{m}^{-2} \mathrm{~s}^{-1}$. In control plant Pg increased curvilinearly up to 29 . $2 \mu \mathrm{mol} \mathrm{m}^{-2} \mathrm{~s}^{-1}$ with increase in light intensity, while in shade-grown plant it was almost saturated at $15.2 \mu \mathrm{mol} \mathrm{m}^{-2} \mathrm{~s}^{-1}$ with a PAR of $1,140 \mu \mathrm{mol} \mathrm{m}^{-2} \mathrm{~s}^{-1}$. Photosynthetic difference between control and shade-grown plants was around $11.8 \mu \mathrm{mol} \mathrm{m}^{-2} \mathrm{~s}^{-1}$ at a PAR of $1,800 \mu \mathrm{mol} \mathrm{m}^{-2} \mathrm{~s}^{-1}$. Mesophyll conductances increased linearly with light intensity 
increase in control plant, but in shade-grown plant the increase was lenient.

Little difference was found in light response curve of $\mathrm{Pg}$ between control and shade-grown black grams (Fig.3); the curves presented a similar, light-unsaturated pattern. The shade-grown plant had higher mesophyll conductances than the control plant at low light intensities.

\section{DISCUSSION}

Dry matter production of a plant is mainly determined by two parameters, photosynthetic rate of single leaf and leaf area. There was a clear specific difference in light-response of the two parameters. Based on the light responses of these parameters the characteristics of production of mungbean and black gram are discussed here.

Mungbean was highly sensitive to light intensity. Photosynthetic rates of single leaf decreased in shade-grown plant (Fig.2). Also the pattern of light photosynthetic response curve was different between control and shade-grown plants (Fig.3); the former had a light-unsaturated pattern and the latter had a light-saturated pattern within the light intensity range adopted here. On the other hand black gram was less sensitive (Fig.2 and 3). Little difference was found in photosynthetic rate and lightphotosynthetic response between control and shade-grown plants.

Mesophyll conductance in mungbean grown in control increased with light intensity increase, while in shade-grown plants it remained at low level (Fig.3). Contrary, the conductance was higher in shade-grown black gram especially at low light intensities, which may suggest that the activity of photosynthetic enzymes such as RuBP. Case was enhanced under the shade growth conditions. This may be responsible for the photosynthetic rise of this species grown in shade.

Black gram is widely grown as an intercropping cultivar in the farming system in Bangladesh. The photosynthetic light-response trait of this species is likely beneficial to realize the stable and high production under the light condition with sun flecks and shades alternating in a short time between or under the rows of taller partner crops such as sugarcane and corn.

In general black gram has a higher production than mungbean under the favorable growth conditions (Lawn and Russell,1978). A similar result was obtained in this experiment; the dry matter production and leaf area of black gram grown in control were considerably higher than that of mungbean (Table 1 and 3). While under the shade conditions dry matter accumulation, PGR, RGR and NAR were higher in mungbean than in black gram (Table 1 and 2). The higher productivity of mungbean primarily depended on leaf area increase with shade (Table 2). Concurrently the structural weakness was observed in shade-grown mungbean. It may be predicted that lodgings and petiole drops occur more seriously under the field conditions and become a cause of the productive reduction.

In a clear day photosynthetic rates of both species reached high levels in the early morning, then decreased with increase in PAR and temperature toward the afternoon (Fig.1). The efficiency of solar energy utilization seems to be largely restricted in both species. High rate of evapo-transpiration is considered as a cause of water deficits in leaf, which may lead to the depletion of stomatal conductance and photosynthetic reduction. 
In this experiment the two leading cultivars, Chinese (mungbean) and MAK-1 (black gram), were used, but many other cultivars including less improved local varieties with various genetic characters are grown in the different cropping systems in Bangladesh. The affluent genetic resources enable diversified selections of the strains with high adaptability to variable growth conditions (Imrie et al., 1982, 1988; Verma et al., 1988). It is also possible to introduce beneficial genetic characters into a plant by interspecific crossing between mungbean and black gram (Lawn and Russell, 1978; Singh et al., 1988; Poehlman, 1991).

As mentioned above, mungbean and black gram are main protein supplying foods in Bangladesh. Also these are much consumed as materials of bean sprouts in Japan today and are becoming important trade products in some countries in Southeast Asia. However photosynthetic characteristics and physiological aspects of these crops have not been well known yet, though some physiological researches have been taken up recently in Japan (Francisco and Maeda, 1989; Hamid et al., 1990; Islam et al., 1992). To progress the genetical and agronomical improvements of these species more information is required in the field of growth and production physiology.

\section{ACKNOWLEDGEMENTS}

The authors are thankful to Dr. W. Agata, Prof. of Kyushu Univ. and Mr. M. T. Islam, Assist. Prof. of IPSA Bangladesh for their helpful advice and information.

\section{REFERENCES}

Francisco, P. B and K. Maeda 1989 Agro-physiological studies on the yield performance of mungbean. II. Cultivaral differences in dry matter production, partitioning and yield components, and their relationships with earliness in flowering. Japan. Jour. Crop Sci., 58: 712-719

Hamid, A.. F. Kubota, W. Agata and M. Morokuma 1990 Photosynthesis, tanspiration, dry matter accumulation and yield performance of mungbean plant in response to water stress. J. Fuc. Agr. Kyushu Univ., 35: 81-92

Imrie, B. C. and K. L. Butler 1982 An analysis of variability and genotype X environmental interaction in mung bean (Vigna radiata) in south-eastern Queensland. Aust. J. Agric. Res., 33: 523-530

Imrie, B. C., R. W. Williams and R. J. Lawn 1988 Breeding for resistance to weather damage in mungbean. Second Int. Mungbean Symp.Proc., 130-135

Islam, M. T., W. Agata and F. Kubota 1992 Studies on dry matter production in mungbean (Vigna radiata (L.) Wilczek). 1. Varietal difference of growth parameters in pre-reproductive phase. Japan. Jour. Crop Sci.,61(Ext.1): 98-99

Islam, M. T., W. Agata and F. Kubota 1992 Studies on dry matter production in mungbean (Vigna radiata (L.)Wilczek). 2. Characteristics of photosynthesis and transpiration. Japan. Jour. Crop Sci., 61(Ext. 1): 100-101

Lawn, R. J. and J. S. Russell 1978 Mungbeans: a grain legume for summer rainfall cropping areas of Australia. J.Aust. Inst. Agric. Sci., 44: 28-41

Lawn, R. J. 1989 Agronomic and physiological constraints to the productivity of tropical grain legumes and prospects for improvement. Expl. Agric., 25: 509-528

Poehlman, J. M. 1991 Cytology, polyploidy, interspecific hybridization, mutation research, and biotechnology, In "The Mungbean” ed. by J. M. Poehlman, Westview Press, Colorado, USA, 153-172 
Rhaman M. M. and A. A. Miah 1988 Mungbean in Bangladesh - Problems and prospects -. Second Int. Mungbean Symp. Proc., 570-579

Singh, P., D. P. Singh, A. Kumar. B. D. Chaudhary and S. K. Thakural 1988 Response of mungbeanblack gram hybrids under water stress conditions. Second Int.Mungbean Symp.Proc., 261-271

Srinivasan, P. S., R. Chandrabaru, N. Natayajaratnam and S. R. Sree Rangaswamy 1985 Leaf photosynthesis and yield potential in green gram (Vigna radiata (L.) Wilczek) cultivars. Trop. Agric, 62: 222-224.

Verma, M. M. and S. S. Sandhu 1988 Development of mungbean varieties for favorable environments - A new selection methodology. Second Int.Mungbean Symp.Proc., 159-163 